University of Nebraska - Lincoln

DigitalCommons@University of Nebraska - Lincoln

Papers in the Earth and Atmospheric Sciences

Earth and Atmospheric Sciences, Department

\title{
Tetrapod Fauna of the Lowermost Usili Formation (Songea Group, Ruhuhu Basin) of Southern Tanzania, with a New Burnetiid Record
}

\author{
Christian A. Sidor \\ University of Washington - Seattle Campus, casidor@u.washington.edu \\ Kenneth D. Angielczyk \\ The Field Museum, Chicago, IL, kangielczyk@fieldmuseum.org \\ D. Marie Weide \\ University of Nebraska-Lincoln, dmweide@huskers.unl.edu
}

Roger M. H. Smith

South African Museum, Cape Town, rsmith@iziko.org.za

Sterling J. Nesbitt

University of Texas at Austin,, nesbitt@jsg.utexas.edu

See next page for additional authors

Follow this and additional works at: https://digitalcommons.unl.edu/geosciencefacpub

Part of the Other Ecology and Evolutionary Biology Commons, Paleobiology Commons, Paleontology Commons, and the Stratigraphy Commons

Sidor, Christian A.; Angielczyk, Kenneth D.; Weide, D. Marie; Smith, Roger M. H.; Nesbitt, Sterling J.; and Tsuji, Linda A., "Tetrapod Fauna of the Lowermost Usili Formation (Songea Group, Ruhuhu Basin) of Southern Tanzania, with a New Burnetiid Record" (2010). Papers in the Earth and Atmospheric Sciences. 375.

https://digitalcommons.unl.edu/geosciencefacpub/375

This Article is brought to you for free and open access by the Earth and Atmospheric Sciences, Department of at DigitalCommons@University of Nebraska - Lincoln. It has been accepted for inclusion in Papers in the Earth and Atmospheric Sciences by an authorized administrator of DigitalCommons@University of Nebraska - Lincoln. 


\section{Authors}

Christian A. Sidor, Kenneth D. Angielczyk, D. Marie Weide, Roger M. H. Smith, Sterling J. Nesbitt, and Linda A. Tsuji 


\title{
Tetrapod Fauna of the Lowermost Usili Formation (Songea Group, Ruhuhu Basin) of Southern Tanzania, with a New Burnetiid Record
}

\author{
Christian A. Sidor, ${ }^{1}$ Kenneth D. Angielczyk, ${ }^{2}$ D. Marie Weide, ${ }^{1}$ \\ Roger M. H. Smith, ${ }^{3}$ Sterling J. Nesbitt, ${ }^{4}$ and Linda A. Tsuji ${ }^{5}$
}

1. Burke Museum and Department of Biology, University of Washington, Seattle, Washington 98195, U.S.A., casidor@u.washington.edu 2. Department of Geology, The Field Museum, 1400 South Lake Shore Drive, Chicago, Illinois 60605, U.S.A., kangielczyk@fieldmuseum.org 3. Karoo Palaeontology, Iziko: South African Museum, Cape Town 8000, South Africa, rsmith@iziko.org.za 4. Jackson School of Geosciences, University of Texas at Austin, 1 University Station, C1100, Austin, Texas 78712, U.S.A., nesbitt@jsg.utexas.edu 5. Museum für Naturkunde, Humboldt-Universität zü Berlin, 10115, Berlin, Germany, linda.tsuji@museum.hu-berlin.de

Current address for D. M. Weide - Department of Earth and Atmospheric Sciences, University of Nebraska-Lincoln, dmweide@huskers.unl.edu Corresponding author - Christian A. Sidor

\begin{abstract}
Vertebrate fossils from the Ruhuhu Basin of southern Tanzania have been known for over 75 years, but the details of their stratigraphic distribution remain imperfectly understood. Recent fieldwork in the Upper Permian Usili Formation (Songea Group) has led to the discovery of a tetrapod assemblage in a conglomeratic unit at its base. The fossils are concentrated in matrix-supported intraformational clay pebble conglomerates interpreted as mass flow deposits in wide, shallow channels in the distal reaches of an alluvial fan. Included in this new collection are fossils representing the first record of a burnetiid therapsid from Tanzania. The anatomy of the interorbital and intertemporal skull roof indicates that the Usili burnetiid most closely resembles Burnetia from the Dicynodon Assemblage Zone of South Africa's Beaufort Group. Review of the Usili Formation tetrapod fauna recognizes 29 genera, 6 of which are endemic (Katumbia, Kawingasaurus, Pachytegos, Peltobatrachus, Ruhuhucerberus, Titanogorgon, as well as a new, undescribed cryptodontian dicynodont). In addition, eight genera are shared between the basal conglomerate and rocks higher in section, which suggests that the available data fail to support the recognition of two faunal horizons within the Usili Formation, as was suggested previously. The recognition of a single (undivided) Usili tetrapod fauna calls for several therapsid genera to have unequal stratigraphic ranges (and temporal durations) in the Ruhuhu and Karoo basins. We suggest that the fine-scale biostratigraphic utility of therapsids likely diminishes between basins, especially when rates of subsidence, depositional setting, and paleoenvironment are taken into consideration.
\end{abstract}

\section{Introduction}

Tetrapod fossils from the Upper Permian of Tanzania were first described by Haughton (1932), after being discovered during the course of geological mapping of the Ruhuhu Basin (Stockley, 1931, 1932; Stockley and Oates, 1931). Subsequent exploration by British and German teams produced a rich vertebrate fauna showing broad similarities to that of the Karoo Basin of South Africa (Parrington, 1936, 1946; Nowack, 1937; von Huene, 1939, 1942, 1944, 1950). Subsequent taxonomic refinements noted the presence of several endemic Permian taxa (e.g., Katumbia parringtoni, Kawingasaurus fossilis, Peltobatrachus pustulatus, Ruhuhucerberus terror), showing that the Ruhuhu fauna was distinctive and that comparisons between the Ruhuhu and Karoo were not necessarily straightforward (Panchen, 1959; Cox, 1972; Maisch, 2002; Angielczyk, 2007). In addition, it was suggested that the Usili Formation (formerly K6 or Kawinga Formation, see Charig, 1963; Kaaya, 1992; Wopfner, 2002) might preserve more than one faunal horizon (von Huene, 1950; Cox, 1959; Maisch, 2002; Rubidge, 2005; although see Gay and Cruickshank, 1998), further complicating biostratigraphic correlation.

We report here on vertebrate fossils recently collected from the base of the Usili Formation (Figure 1). Among these fossils is an isolated skull roof referable to Burnetiidae, which represents the first record of this group in Tanzania and only the sec- ond from East Africa (Jacobs et al., 2005). Based on comparisons with tetrapod collections derived from higher in the Usili Formation, we suggest that the available data best support the recognition of only a single tetrapod fauna in this formation.

Institutional Abbreviations: BMNH, Natural History Museum, London; MAL, Malawi Department of Antiquities, Lilongwe; NMT, National Museum of Tanzania, Dar es Salaam; PIN, Paleontological Institute, Moscow; SAM, Iziko: South African Museum, Cape Town; UMCZ, University of Cambridge Museum of Zoology, Cambridge.

\section{Geological Context}

Stratigraphy and Sedimentology - The main Karoo Basin of South Africa was one of several retro arc foreland sag basins formed from the early Carboniferous through to Early Jurassic on the landward side of a subduction-driven thrust belt along the southern margin of Gondwana. At the same time, weaknesses in the crust to the north of the foreland sag were subjected to a series of extensional episodes that resulted in numerous pullapart rifts, grabens, and half-grabens that were rapidly filled with locally derived terrestrial sediments. Today, these small fault-bounded basins occur in a roughly northeast-southwest trending corridor extending from the coast of Kenya through Tanzania, Malawi, Mozambique, and Zambia, and terminating in Zimbabwe. The best exposed and the 
most complete stratigraphic succession of Karoo-aged strata in these rift basins is the Songea Group in the Ruhuhu half-graben located in southern Tanzania (Stockley and Oates, 1931; Stockley, 1932; Kreuser, 1990; Kaaya, 1992; Wopfner, 2002; Catuneanu et al., 2005).

Songea Group rocks range in age from Pennsylvanian to Anisian (Middle Triassic) and have been divided into six formations and one informally recognized unit (viz. Idusi, Mchuchuma, Mbuyura, Mhukuru, Ruhuhu, and Usili formations and the informal Manda Beds, which include the Kingori Sandstone and Lifua Member; Wopfner, 2002; Figure 1). The Usili Formation (formerly K6 or Kawinga Formation) is considered Late Permian in age (Parrington, 1936; Wopfner and Kreuser, 1986; Wopfner, 2002). It is possible that the Usili Formation preserves the Permo-Triassic boundary in its uppermost $50 \mathrm{~m}$ of strata beneath the sharply contacted base of the Kingori Sandstone (the lowermost member of the overlying Manda Beds). To date, however, no marker fossils for the Permo-Triassic boundary, such as Lystrosaurus mccaigi, have been discovered in the upper portion of the Usili.

The Usili Formation is a 260 -m-thick fluvio-lacustrine succession made up of a lowermost conglomeratic interval approximately $5 \mathrm{~m}$ thick, grading up into a trough cross-bedded, coarse-grained sandstone-dominated interval 25-40 m thick, overlain by massive nodular siltstone and laminated mudstone beds with minor ribbon sandstones forming the bulk of the succession (Wopfner et al., 1991).

The basal intraformational conglomerates comprise three fining-upward sequences comprising erosively based lenticular bodies of clast-supported conglomerate overlain by gritstone and coarse to fine sandstone beds. The clasts immediately overlying the erosion surface are predominantly cobble-sized spherical and oblate calcareous nodules, the latter with distinct stromatolitic textures. These conglomerates are clearly derived from erosion of the underlying Ruhuhu Formation. They are overlain by a more extensive tabular beds of matrix-supported clay pebble conglomerate with abundant haematite-encrusted fossil bones and gritstone beds with fine sandstone matrix containing some pebble-sized extrabasinal quartzite clasts. The uppermost levels of the second sequence contain numerous silicified tree trunks that are much more resistant to weathering than the host matrix and can be used as a local marker horizon. The Usili conglomeratic sequences are similar to those described by Mack and Leeder (1999) from distal facies of semi-arid alluvial fans in the Plio-Pleistocene Palomas half graben, southern Rio Grande Rift. During a protracted period of fault movement, the interplay of channel downcutting, infilling with mass flow pebbly sandstones and axial river truncation led to stacked sequences of 3-10 m cyclothems similar to the Ruhuhu conglomeratic sequences (Mack and Leeder, 1999).

We conclude that the overall decrease in grain size in the Usili succession reflects the declining energy regimes in the graben as the fluvial systems accommodated increased sediment load immediately following subsidence events (prograding alluvial fans into an axial braided channel) before approaching an equilibrium base level condition whereby the rift floor was occupied by a wide alluvial plain with meandering rivers and axial lakes.

Vertebrate Taphonomy - Vertebrate fossils occur throughout the stratigraphic range of the Usili Formation and their relative abundance and taphonomic style is strongly linked to the depositional environment. The lowermost Usili strata are characterized by intraformational conglomerates that contain abundant vertebrate remains, but only as accumulations of isolated elements from numerous taxa. No articulated skeletons and only very rare associated elements were recorded in these meter-thick clast-supported sheets of reworked pedogenic/paludal carbonate nodules. Bones can be complete and un-abraded
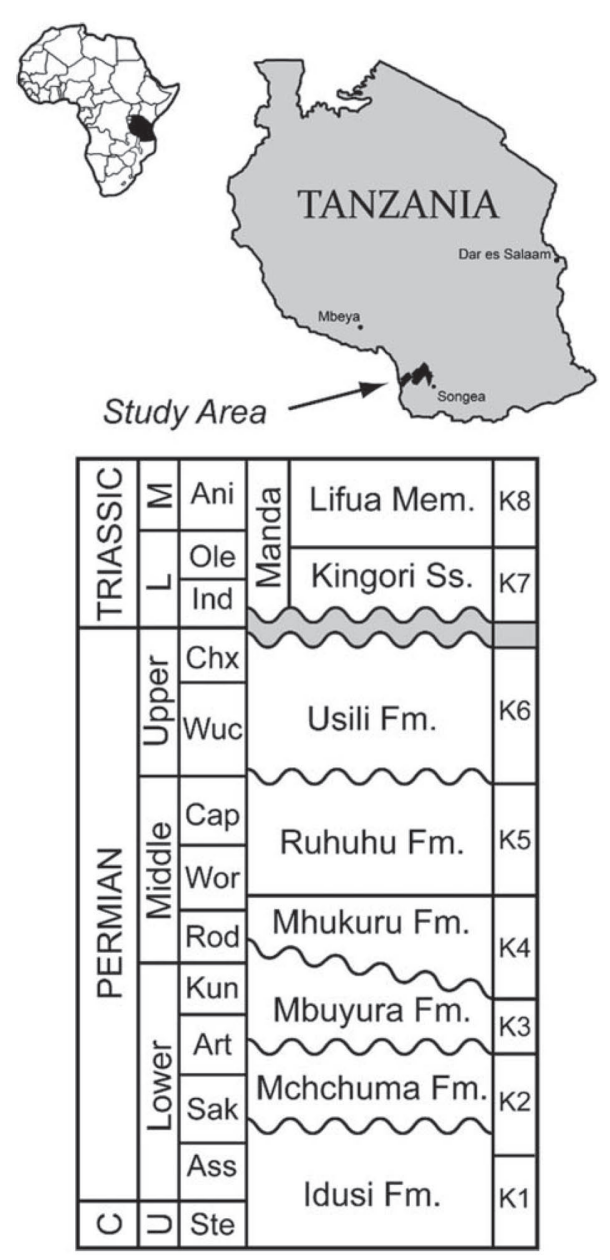

Figure 1. Generalized stratigraphy and geographic location of the Songea Group (Ruhuhu Basin). Correlations between lithostratigraphy and marine stages based on Wopfner (2002).

(e.g., the large gorgonopsian canine still has its delicate tip and serrations intact), although pervasive perimineralization with dark red haematitic nodular material makes it difficult to assess surface damage on these bones until they have been prepared.

The accumulation mechanism for this extensive bone-rich interval at the base of the Usili Formation is linked to local erosion of the freshly exposed stromatolitic carbonate mudflats along the edge of the shrinking axial lake. This is evidenced by the clast composition of the cobble conglomerates that are clearly derived from the underlying Ruhuhu Formation. The overlying clast-supported pebbly gritstone contains a few extrabasinal clasts as well as numerous bone fragments suspended in the structureless groundmass. This is interpreted as a mass flow deposit (Mack and Leeder, 1999) within a shallow channel in the distal reaches of an alluvial fan. From the scattering and mixing of bones of various taxa and their chaotic orientation in an intraformational clay-pebble conglomerate, it is possible they were derived from carcasses that accumulated in the channels during a long dry spell and their disarticulated skeletal elements became entrained in a high-density mass flow event as flow resumed in the next rainy season.

Higher in the Usili succession there are at least two approximately 5-m-thick intervals where vertebrate fossils are relatively more abundant, with fossils occurring in clusters every 50-100 $\mathrm{m}$ along strike. The specimens comprise mainly large dicynodonts (semi-articulated and scattered but associated skeletons), although in places large gorgonopsians are over-represented 
(three large skulls on a single $50-\mathrm{m}^{2}$ outcrop), suggesting some behavioral accumulation mechanism such as scavenging at a mire or quicksand trap. Smaller taxa are represented in abundance at other sites yielding multiple articulated (rarely fully articulated and curled-up specimens) of the small dicynodont $\mathrm{Di}$ cynodontoides (formerly Kingoria; see Angielczyk et al., 2009a).

In the middle portion of the Usili, bone-rich localities are hosted by fissile greenish gray and silty mudstone with large (up to $35 \mathrm{~cm}$ diameter), spherical smooth-surfaced brown weathering calcareous nodules with internal septarian shrinkage cracks and distinctive 'anastomoses' of thin calcite veins. The macroscopic structure of bones is perfectly preserved (i.e., bone surface intact and unweathered, although histological structure is not reliably preserved) within the mudrocks. Specimens are uncrushed and they lack the thick ferruginous encrustation that is so pervasive lower in the succession. The bone is dark gray, with dark red/purple surface staining and sometimes a thin (2-mm-thick) light gray calcareous crust. In places, several large skulls are surrounded by brown weathering calcareous nodular growth that completely masks the original shape of the skull. The interpreted depositional setting for the middle part of the Usili Formation is an alluvial plain with narrow distributary channels meandering across well-vegetated floodplains with generally high water table. Seasonal drying caused calcium carbonate to be precipitated around roots in the B horizons of floodplain soils and as large spherical nodules in marginal lacustrine areas (Calvo et al., 1989). Bones were most commonly buried in the greenish mudrock facies that is interpreted as distal floodplain deposits away from the channel margins (Smith, 1990).

Towards the top of the Usili Formation (upper $50 \mathrm{~m}$ ), dark reddish brown mudrock intervals become more common, until they dominate the succession. The calcareous nodular horizons in this facies are more prominent and comprise numerous individual cobble- to boulder-sized white-weathering oblate-shaped nodules, fairly irregularly packed into meter-thick horizons. In places this BCa horizon displays slicken-sided claystone-lined skew planes and it is apparent that some of the nodules are vertically stacked along root channels. The vertebrate fossils found in this facies are rarer and more disarticulated, typically occurring as isolated elements. However, approximately 50 stratigraphic meters below the base of the Kingori Sandstone there is an interval of gray/green mudrocks that contain abundant articulated large "Dicynodon" skeletons preserved within large rounded, brown calcareous nodules.

\section{Systematic Paleontology}

\section{Therapsida Broom, 1905 \\ Burnetiamorpha Broom, 1923 \\ Burnetiidae Broom, 1923}

Referred Material-NMT RB4, partial skull roof including dorsal margin of orbits and parietal foramen (Figure 2); NMT RB36, fragmentary right dorsal margin of orbit.

Horizon and Locality - Collected from a small outcrop located approximately $4 \mathrm{~km}$ west of the town of Litumba Ndyosi (Songea District, Ruvuma Province, Tanzania) at $10^{\circ} 23.404^{\prime} S$, 355.999'E.

Taxonomic Comment-The incompleteness of the material does not permit unambiguous referral to a known burnetiid genus. However, our comparisons suggest that NMT RB4 most closely resembles Burnetia mirabilis.

\section{Description \\ Skull Roof}

Based on comparison with other therapsids, it is likely that NMT RB4 preserves the frontals and parietale as well as parts of the prefrontals, the postfrontals, and the postorbitals. However, as with most other burnetiid fossils, the delineation of sutures is exceptionally difficult. The specimen is somewhat rectangular in dorsal or ventral views, consisting mostly of the interorbital portion of the skull roof. The anterior and posterior margins of the specimen are broken, likely as a result of transport, but the orbital margins are generally complete. Overall, NMT RB4 is slightly smaller than the corresponding region in Burnetia (BMNH R5397) or Proburnetia (PIN 2416/1).

Dorsal View - The most prominent feature in dorsal view is an elongate, parasagittally oriented boss above each orbit (Figure 2A). As in Burnetia, this structure is vaguely sigmoidal and becomes progressively further inset from the orbital margin posteriorly. At the posterior end of this boss, in the region typically occupied by the postfrontal and the postorbital, another thickening is present. This second boss is better developed in Burnetia and Bullacephalus, where it forms a distinct protrusion, but in NMT RB4 the two supraorbital bosses above each orbit are poorly differentiated.

The anterior portion of the interorbital region is relatively flat, but posteriorly a gentle median frontal ridge is formed. This ridge is narrowest anteriorly and widens posteriorly, where it blends into the thickened bone surrounding the parietal foramen. As such, this structure conforms favorably to the condition seen in Bullacephalus and Burnetia. As in other burnetiids, it is unclear to what degree the parietale contributed to the median ridge.

The parietal foramen is almost perfectly round in dorsal view and is situated near the posterior one-third of the specimen. The bone surrounding the foramen appears spongy and slightly thickened, but does not display the prominent 'chimney' commonly observed in basal therapsids (e.g., Lemurosaurus or Suminia). Behind the parietal foramen, the midline remains thickened between posteromedially tapering depressions. At the posterior margin of the skull roof, the bone angles sharply downwards, suggesting that part of the postparietal contribution to the occiput is preserved.

Ventral View - Among burnetiamorphs, the ventral surface of the skull roof is accessible only in Proburnetia, which limits useful comparisons. However, the anatomy preserved in NMT RB4 is remarkably similar. Readily apparent are the longitudinal ridges that bound a median trough (Figure 2B). Each ridge is bowed medially, suggesting the curved medial margin of the orbit, and where the sphenethmoid would have sutured (Sidor and Smith, 2007). The median trough is widest at the level of the parietal foramen and likely housed the brain and olfactory tract in life (Tatarinov, 1968). As in Proburnetia, the trough widens slightly anteriorly, near the specimen's broken anterior margin.

In contrast to the condition observed in dorsal view (Figure $2 \mathrm{~A})$, the outline of the parietal foramen is oval ventrally (Figure $2 \mathrm{~B}$ ). This discrepancy occurs because the posterior wall of the parietal foramen slopes downwards and backwards, whereas its anterior wall is vertical. The posterior wall bears a small median ridge. A similar ridge occurs in Proburnetia and Dimetrodon (Romer and Price, 1940: pl. 11).

Present on each side of the ventral surface is a large fossa representing the dorsal margin of the orbit. Openings for a few, small (presumably vascular) foramina are visible on the otherwise smooth and featureless area. At the level of the parietal foramen, a sharp ridge extends transversely to the broken lateral margins of the specimen. As in Proburnetia, this ridge separates the dorsal roof of the orbital and temporal cavities. On the right side, the ridge reaches the remnants of the postorbital bar. What little is left of the underside of the temporal roof is smooth.

Lateral View-Figure 2C shows NMT RB4 in left lateral view. We interpret the temporal region as sloping posteroventrally, as suggested for most biarmosuchians (Sigogneau-Russell, 1989; Sidor and Rubidge, 2006). 

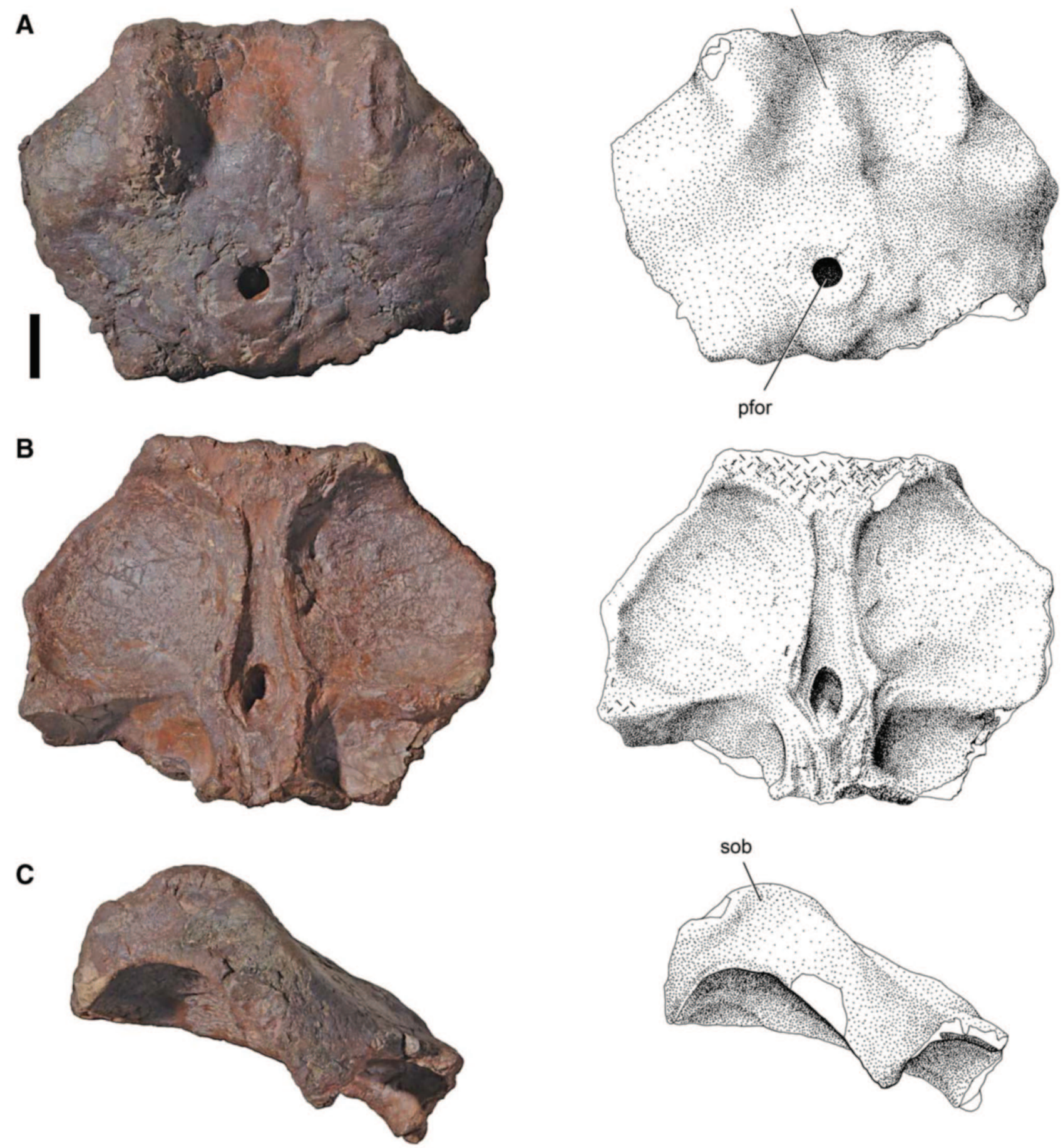

Figure 2. Skull roof of burnetiamorph (NMT RB4) from the basal conglomerate of the Usili Formation. A, dorsal view; B, ventral view; C, left lateral view. Abbreviations: fb, median frontal boss; pfor, parietal foramen; sob, supraorbital boss. Scale bar equals $1 \mathrm{~cm}$.

\section{Discussion}

\section{Identity and Relationships of the New Burnetiamorph}

NMT RB4 can be confidently referred to the Burnetiamorpha (sensu Sidor and Welman, 2003) because, as in all other members of this clade, the supraorbital margin is thickened into a prominent structure. Several Middle Permian dinocephalians display similar pachyostosis (although they are uniformly much larger animals; Boonstra, 1968), but no other tetrapod from the Upper Permian shows this condition. Within Bumetiamorpha, many diagnostic features of the subclade Burnetiidae (sensu Rubidge and Sidor, 2002) are not preserved in NMT RB4. However, the presence of a low swelling around the parietal foramen was found by Sidor and Smith (2007) to be a character state reversal diagnostic of Burnetiidae, suggesting that the Usili specimen belongs to this clade. Further evidence for this assignment comes from the presence of a secondary thickening at the posterodorsal margin of the 

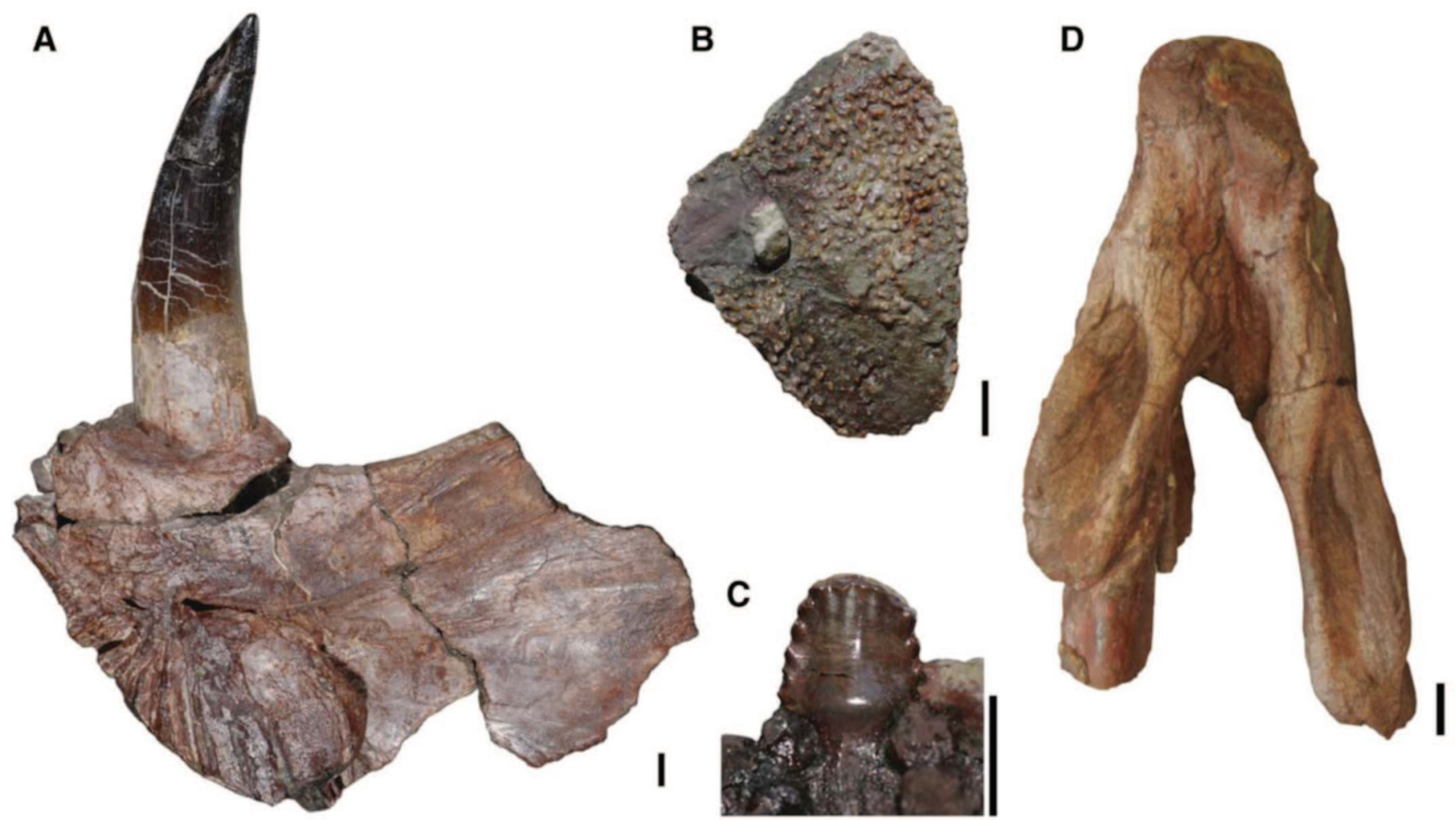

Figure 3. Representative tetrapod fossils from the basal conglomerate of the Usili Formation. A, anterior portion of large gorgonopsian dentary in medial view (NMT RB5); B, osteoderm of Peltobatrachus in external view (NMT RB6); C, isolated pareiasaur tooth (cf. Pareiasaurus) in lingual view (NMT RB8); D, partial lower jaw of Dicynodontoides in dorsal view (NMT RB7). Scale bars equal $1 \mathrm{~cm}$.

orbit. This feature, in addition to the pachyostosis of the supraorbital margin, is present in burnetiids such as Bullacephalus, Burnetia, and Pachydectes (see Rubidge and Sidor, 2002; Rubidge and Kitching, 2003; Rubidge et al., 2006). Finally, the low midline ridge on the frontals and gentle sigmoidal curvature of the supraorbital thickening in dorsal view is most similar to the condition seen in Burnetia among burnetiamorphs (Rubidge and Sidor, 2002: fig. 1), further reinforcing a burnetiid identification for NMT RB4.

Of all the burnetiamorph fossils described, NMT RB4 compares most closely with Burnetia mirabilis from the Upper Permian Dicynodon Assemblage Zone of South Africa (Rubidge and Sidor, 2002). Unfortunately, the fragmentary nature of the available Usili burnetiamorph material precludes a definitive generic assignment. We consider the geographically closest burnetiamorph, MAL 290 (from the Chiweta Beds of Malawi; Jacobs et al., 2005), most likely to be a member of the Proburnetia lineage and therefore not especially closely related to NMT RB4. Nonetheless, faunal similarities between the Chiweta Beds and the Usili Formation suggest that these strata may be coeval (see below).

\section{Tetrapod Fauna of the Usili Formation}

The tetrapod fauna of the Usili Formation was summarized by Schlüter and Kohring (1997) and Gay and Cruickshank (1999). Since then, several studies have revised the taxonomy of Tanzanian therapsids (Maisch, 1995, 1999, 2000, 2002, 2004; Abdala and Allinson, 2005; Maisch and Gebauer, 2005; Angielczyk, 2007; Angielczyk et al, 2009a), which yields a revised faunal list including 29 genera (Table 1). However, lists such as this imply the presence of a single fauna through- out the thickness of the geological formation, which has been disputed. It should be noted that Nowack (1937) reported fossils from several horizons in the Usili, but the majority of historical collections lack detailed stratigraphic data, suggesting that finer resolution will be difficult to obtain. Moreover, our experience suggests that Usili vertebrate biostratigraphy will remain problematic for more than selected sections, because the patchy outcrops within the Ruhuhu Valley are not easily correlated. Finally, the fauna given in Table 1 is undoubtedly an incomplete picture of the Usili vertebrate community, as it lacks any fish, diapsid reptiles, or microvertebrates, and the taxonomy of some groups is still in flux (most notably for the genus Dicynodon).

Von Huene (1950) proposed that the Usili Formation contained two faunal zones, which he correlated with the Cistecephalus and Endothiodon zones of South Africa (= Pristerognathus, Tropidostoma, and Cistecephalus assemblage zones of Rubidge, 1995). This suggestion was essentially reiterated by Cox (1959), who argued that the occurrence of Endothiodon low in the Usili ( $\sim 30 \mathrm{~m}$ from its base) and its absence higher up was biostratigraphically useful. Cox (1964:23) later mentioned that Endothiodon also occurred in the underlying Ruhuhu Formation (see also Attridge et al., 1964; Cox, 1991). Although this occurrence has yet to be formally documented, the presence of Endothiodon in the Ruhuhu Formation now appears unlikely given the preservation style of the specimens and others collected at the same localities (Angielczyk, pers. observ., 2009) and new discoveries that point to an Eodicynodon or Tapinocephalus zone correlation for the formation (Angielczyk et al., 2009b). Gay and Cruickshank (1999) reviewed the literature records and rejected previous proposals of a vertical subdivision of the Usili fauna. 
Table 1. Tetrapod fauna of the Upper Permian Usili Formation (Songea Group) of southern Tanzania.

\begin{tabular}{|c|c|}
\hline Taxonomic group & Reference \\
\hline \multicolumn{2}{|l|}{ TEMNOSPONDYLI } \\
\hline Peltobatrachus pustulatus & Panchen, 1959 \\
\hline \multicolumn{2}{|l|}{ REPTILIA } \\
\hline Anthodon serrarius & Haughton, $1932^{\mathrm{a}}$ \\
\hline Pareiasaurus serridens & von Huene, 1944 \\
\hline \multicolumn{2}{|l|}{ THERAPSIDA } \\
\hline Aelurognathus? parringtoni & von Huene, 1950; Maisch, 2002 \\
\hline Aloposaurus? broomianus & von Huene, 1950; Maisch, 2002 \\
\hline Arctognathus? nasutus ${ }^{b}$ & von Huene, 1950; Maisch, 2002 \\
\hline Burnetiidae indet. & This paper \\
\hline Cryptodontia n. g. \& sp. & Unpublished data (NMT RB22) \\
\hline 'Dicynodon' bathyrhynchus ${ }^{\mathrm{C}}$ & von Huene, 1942 \\
\hline ‘Dicynodon' huenei ${ }^{\mathrm{C}}$ & Haughton, 1932 \\
\hline Dicynodon lacerticeps & Kaaya, 1992; Wild et al., 1993 \\
\hline 'Dicynodon' leoniceps ${ }^{\mathrm{C}}$ & Gay and Cruickshank, 1999 \\
\hline 'Dicynodon' roberti' ${ }^{C}$ & $\begin{array}{l}\text { Boonstra, 1953; Gay and } \\
\text { Cruickshank, } 1999\end{array}$ \\
\hline 'Dicynodon' tealei ${ }^{\mathrm{C}}$ & Haughton, 1932 \\
\hline Dicynodontoides nowacki & $\begin{array}{l}\text { von Huene, 1950; Maisch, 2002; } \\
\text { Angielczyk, } 2007\end{array}$ \\
\hline Dinogorgon quinquemolaris & von Huene, 1950; Maisch, 2002 \\
\hline Endothiodon cf. bathystoma & Haughton, 1932; Cox, 1964 \\
\hline Endothiodon sp. nov. ${ }^{\mathrm{d}}$ & Cox, 1964, 1991 \\
\hline Endothiodon uniseries & $\begin{array}{l}\text { Parrington in Haughton, 1932; } \\
\text { Cox, } 1964\end{array}$ \\
\hline Geikia locusticeps & Maisch and Gebauer, 2005 \\
\hline Gorgonops sp. & Gay and Cruickshank, 1999 \\
\hline Katumbia parringtoni & Angielczyk, 2007 \\
\hline Kawingasaurus fossilis & Cox, 1972; Angielczyk, 2007 \\
\hline Leontocephalus intactus $\mathrm{e}$ & Gay and Cruickshank, 1999 \\
\hline Leontocephaus haughtoni & von Huene, 1950; Maisch, 2002 \\
\hline Lycaenops sp. $\mathrm{e}^{\mathrm{e}}$ & Gay and Cruickshank, 1999 \\
\hline Oudenodon bainii & $\begin{array}{l}\text { Gay and Cruickshank, 1999; } \\
\text { Botha and Angielczyk, } 2007\end{array}$ \\
\hline Pachytegos stockleyi & Haughton, 1932; Cox, 1964 \\
\hline Pristerodon mackayi $\mathrm{f}$ & Unpublished data (NMT RB38) \\
\hline Procynosuchus delaharpeae & $\begin{array}{l}\text { von Huene, 1950; Abdala \& All- } \\
\text { inson, 2005; Weide et al., } 2009\end{array}$ \\
\hline Rhachiocephalus behemoth & $\begin{array}{l}\text { von Huene, 1942; Maisch, } \\
\text { 2005; Angielczyk, } 2007\end{array}$ \\
\hline Rhachiocephalus magnusg & $\begin{array}{l}\text { von Huene, 1942; Maisch, 2000, } \\
\text { 2003, } 2004\end{array}$ \\
\hline Ruhuhucerberus terror & Maisch, 2002 \\
\hline Scylacops capensis & Maisch, 2002 \\
\hline Silphoictidoites ruhuhuensis & Maisch, 2002 \\
\hline Sycosaurus? kingoriensis & von Huene, 1950; Maisch, 2002 \\
\hline Theriognathus microps & von Huene, 1950; Maisch, 2002 \\
\hline Titanogorgon maximus & von Huene, 1950; Maisch, 2002 \\
\hline
\end{tabular}

Taxa recovered from the basal conglomerate are in bold.

a. Originally termed Anthodon minisculus, but this species was considered a junior synonym of A. serrarius by Lee (1997).

b. This taxon was considered to belong to an endemic genus by Gebauer (2007).

c. King (1988) recognizes these species of Dicynodon as valid. However, the alpha taxonomy of the genus is badly in need of revision (Angielczyk and Kurkin, 2003). We provisionally consider the Tanzanian species to be referable to $D$. huenei, because it is the oldest species named from the Ruhuhu Basin.

d. \%This is the Endothiodon material that Attridge et al. (1964) and Cox $(1964,1991)$ considered to originate in the Ruhuhu Formation. Based on the style of preservation of these specimens and other specimens collected at the same localities, as well as the geographic and stratigraphic position of those localities relative to our lower Usili Formation localities, we suggest that these specimens most likely originated in the basal conglomerate of the Usili Formation.

e. Maisch (2002) questions the identification of these taxa.

f. Previous reports by King $(1988,1992)$, King and Rubidge (1993), and Gay and Cruickshank (1999) were based on incorrect identification of the holotype of Katumbia parringtoni (see Angielczyk, 2007). A new, diagnostic specimen of Pristerodon mackayi was discovered in 2008.

g. Based on specimens observed in the field as well as fragmentary, unnumbered material at the $\mathrm{BMNH}$ with preservation style and provenance consistent with basal conglomerate.

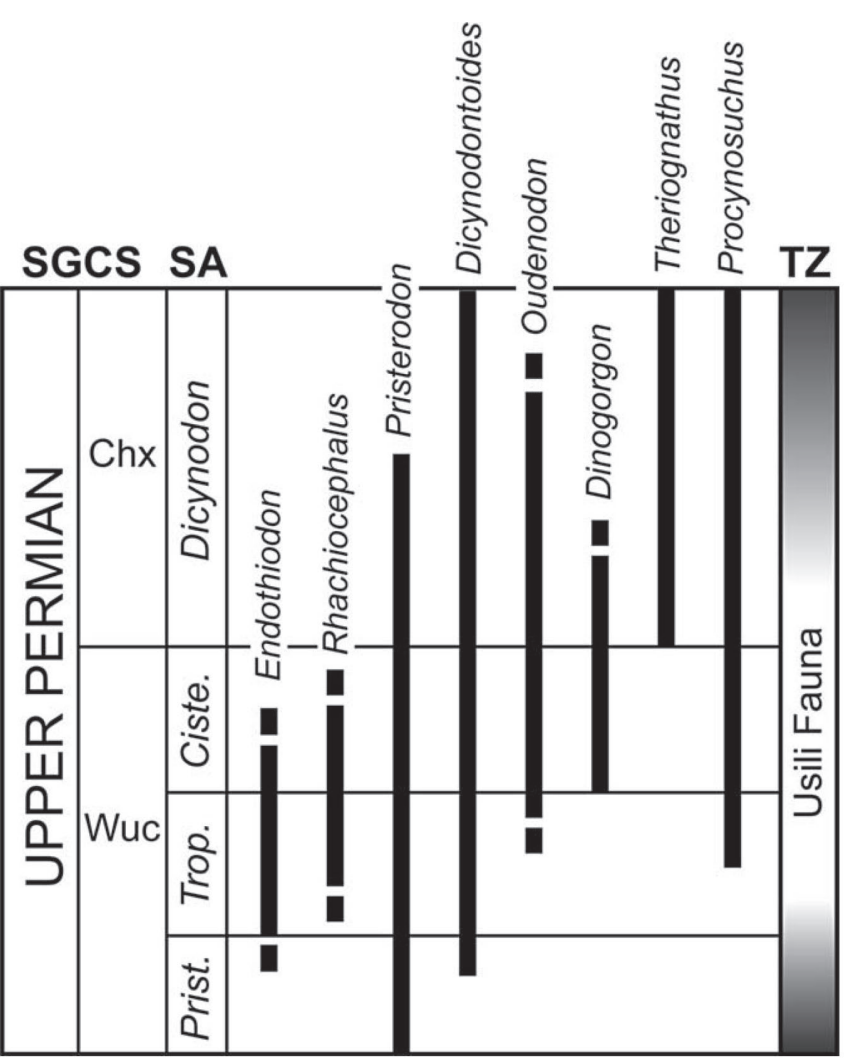

Figure 4. Biostratigraphic comparison of the South African Beaufort Group (Karoo Basin) and the Tanzanian Songea Group (Ruhuhu Basin). Stratigraphic ranges of six therapsid genera common to both basins are plotted (ranges apply to the Karoo Basin and are based on primarily on Rubidge, 1995, with updates from Botha and Smith, 2006; Botha-Brink and Abdala, 2008; and Angielczyk et al., 2009a). Abbreviations: SA, South African vertebrate assemblage zones; SGCS, standard global chronostratigraphic scale, TZ, biostratigraphic correlation of the vertebrate fauna of the Tanzanian Usili Formation.

Fossils from the base of the Usili Formation have received surprisingly little attention, despite their potential for shedding light on the stratigraphic distribution of tetrapods. Nowack (1937: fig. 7) reported fossils from the basal conglomerate of the Usili Formation at Mpelisi. The field numbers corresponding to this level $(\mathrm{S} 1, \mathrm{~S} 30)$ were among the material sent to Cambridge, much of which was subsequently discarded on account of its fragmentary nature. The specimens S1 and S30 were not found during two recent searches of the UMZC collections (one conducted by K.D.A., and the other by M. Lowe), and it is likely that they were among the material discarded. No description of S30 is available in unpublished records of the UMZC, and S1 is described as "a septarian nodule with bone" (M. Lowe, pers. comm., 2009).

Our collection from the basal conglomerate documents the presence of eight taxa (bold font in Table 1; Figure 3), six of which are known from higher in the Usili Formation. Notable among this collection is a lower jaw of Dicynodontoides (Figure 3D) and skull roof of Rhachiocephalus, both of which were previously recorded only near the middle of the Usili Formation (Gay and Cruickshank, 1999: table 4). In addition, fossils of large gorgonopsians (Figure 3A), although not generically identifiable, are very similar in size to the higher occurring Dinogorgon and Titanogorgon. Finally, although little weight can be afforded to absence data, we failed to find material of Endothiodon, the genus considered characteristic of the lower faunal horizon (von Huene, 1950; Cox, 1959) in the basal conglomerate. The one specimen of Endothiodon we re- 
covered (NMT RB23; a skull fragment consisting of parts of the right maxilla and palatine) was found at a stratigraphic level above the basal conglomerate, and in close proximity to localities that have produced specimens of Dicynodontoides, Rhachiocephalus, and a new cryptodontian dicynodont. In summary, we concur with Gay and Cruickshank (1999) and suggest that the available data do not currently support the recognition of distinct faunal horizons within the Usili Formation.

\section{Biostratigraphic Implications}

Recent studies have uniformly come to the conclusion that the Usili Formation is Upper Permian and thus should be correlated with the Teekloof and/or Balfour formations of South Africa (Schlüter and Kohring, 1997; Catuneanu et al., 2005; Rubidge, 2005). More specifically, comparison of Usili tetrapods with those of the lower Beaufort Group has suggested a broad biostratigraphic correlation with the Cistecephalus, Dicynodon, and Tropidostoma assemblage zones (Rubidge, 1995, 2005; Gay and Cruickshank, 1999; Weide et al., 2009).

The recognition of a single (undivided) Usili tetrapod fauna suggests that several therapsid genera have unequal stratigraphic ranges (and temporal durations) in the Ruhuhu and Karoo basins. For example, the therapsids Rhachiocephalus and Theriognathus are considered to have disjunct stratigraphic ranges in the Karoo Basin: the former is found in the Tropidostoma and Cistecephalus assemblage zones, whereas the latter occurs in the higher Dicynodon zone (Rubidge, 1995). However, in the Ruhuhu Basin these taxa co-occur in the Usili Formation, with Theriognathus sometimes occurring below Rhachiocephalus, according to Nowack (1937; see also Maisch, 1999). Figure 4 shows the stratigraphic distribution of several wellknown therapsid genera in the Karoo Basin, all of which are readily identifiable and intermingle within the Usili Formation. These comparisons suggest that therapsids, long recognized for their biostratigraphic utility within the Karoo Basin, likely become less precise markers when geographic distance and depositional setting are considered.

Jacobs et al. (2005) recently revisited the age and therapsid fauna of the Chiweta Beds of Malawi (Dixey, 1926; Haughton, 1926), and they noted the presence of Aelurognathus, Endothiodon cf. E. bathystoma, Oudenodon baini, Gorgonops? dixeyi, and a burnetiid (MAL 290). In addition, Angielczyk et al. (2009a) noted that Dicynodontoides is present in Malawi, and undescribed material documents the presence of Rhachiocephalus (SAM-PK-7861) and an indeterminate tusked dicynodont (SAM-PK-7862, SAM-PK-7863). Except for the burnetiid, the Usili Formation hosts identical genera. This degree of faunal similarity, coupled with their geographic proximity (on either side of Lake Nyasa), suggests that the two sets of exposures might represent parts of the same original basin.

Acknowledgments - Fieldwork in Tanzania has been supported by National Geographic Committee for Research and Exploration Grant 7787-05 (to C.A.S.), with additional support from NSF DBI-0306158 and The Grainger Foundation (to K.D.A.). We thank C. Saanane (University of Dar es Salaam) as well as L. Nampunju and A. Tibaijuka (Antiquities Division, Ministry of Natural Resources and Tourism) for assistance in arranging and carrying out the fieldwork. C. B. Cox graciously allowed K.D.A. to examine undescribed Tanzanian Endothiodon specimens that he is currently studying. M. Lowe provided valuable assistance with Ruhuhu Basin specimens in the UMZC collections. Finally, we acknowledge B. Crowley (Burke Museum), L. Herzog and A. Shinya (The Field Museum), and A. Crean (SAM) for preparation of the specimens discussed herein and J. Swales for the illustrations in Figure 2.

\section{Literature Cited}

Abdala, F., and M. Allinson. 2005. The taxonomic status of Parathrinaxodon proops (Therapsida: Cynodontia), with comments on the morphology of the palate in basal cynodonts. Palaeontologia Africana 41:45-52.

Angielczyk, K. D. 2007. New specimens of the Tanzanian dicynodont "Cryptocynodon" parringtoni von Huene, 1942 (Therapsida, Anomodontia), with an expanded analysis of Permian dicynodont phylogeny. Journal of Vertebrate Paleontology 27:116-131.

Angielczyk, K. D., and A. A. Kurkin. 2003. Has the utility of Dicynodon for Late Permian terrestrial biostratigraphy been overstated? Geology 31:363-366.

Angielczyk, K. D., C. A. Sidor, S. J. Nesbitt, R. M. H. Smith, and L. A. Tsuji. 2009a. Taxonomic revision and new observations on the postcranial skeleton, biogeography, and biostratigraphy of the dicynodont genus Dicynodontoides, the subjective senior synonym of Kingoria (Therapsida, Anomodontia). Journal of Vertebrate Paleontology 29:1174-1187.

Angielczyk, K. D., C. A. Sidor, R. M. H. Smith, J.-S. Steyer, and N. J. Gostling. 2009b. A re-evaluation of the dicynodonts (Therapsida, Anomodontia) of the Permian Ruhuhu Formation (Songea Group, Ruhuhu Basin), Tanzania. Journal of Vertebrate Paleontology 29 (Supp. to Issue 3):55A.

Attridge, J., H. W. Ball, A. J. Charig, and C. B. Cox. 1964. The British Museum (Natural History) - University of London joint palaeonto-logical expedition to Northern Rhodesia and Tanganyika, 1963. Nature 201:445-449.

Boonstra, L. D. 1953. A report on a collection of fossil reptilian bones from Tanganyika Territory. Annals of the South African Museum 42:5-18.

Boonstra, L. D. 1968. The braincase, basicranial axis and median septum in the Dinocephalia. Annals of the South African Museum 50:195-273.

Botha, J., and K. D. Angielczyk. 2007. An integrative approach to distinguishing the Late Permian dicynodont species Oudenodon bainii and Tropidostoma microtrema (Therapsida: Anomodontia). Palaeontology 50:1175-1209.

Botha, J., and R. M. H. Smith. 2006. Rapid vertebrate recuperation in the Karoo Basin of South Africa following the end-Permian extinction. Journal of African Earth Sciences 45:502-514.

Botha-Brink, J., and F. Abdala. 2008. A new cynodont record from the Tropidostoma Assemblage Zone of the Beaufort Group: implications for the early evolution of cynodonts in South Africa. Palaeontologia Africana 43:1-6.

Broom, R. 1905. On the use of the term Anomodontia. Records of the Albany Museum 1:266-269.

Broom, R. 1923. On the structure of the skull in the carnivorous dinocephalian reptiles. Proceedings of the Zoological Society of London 2:661-684.

Calvo, J. P., A. M. Alonso Zara, and M. A. Carcia del Cura. 1989. Models of Miocene marginal lacustrine sedimentation in response to varied depositional regimes and source areas in the Madrid Basin (Central Spain). Palaeogeography, Palaeoclimatology, Palaeoecology 70:199-214.

Catuneanu, O., H. Wopfner, P. G. Eriksson, B. Cairncross, B. S. Rubidge, R. M. H. Smith, and P. J. Hancox. 2005. The Karoo basins of south-central Africa. Journal of African Earth Sciences 43:211-253.

Charig, A. J. 1963. Stratigraphical nomenclature in the Songea Series of Tanganyika. Records of the Geological Survey of Tanganyika 10:47-53.

Cox, C. B. 1959. On the anatomy of a new dicynodont genus with evidence of the position of the tympanum. Proceedings of the Zoological Society of London 132:321-367.

Cox, C. B. 1964. On the palate, dentition, and classification of the fossil reptile Endothiodon and related genera. American Museum Novitates 2171:1-25.

Cox, C. B. 1972. A new digging dicynodont from the Upper Permian of Tanzania; pp. 173-189 in K. A. Joysey and T. S. Kemp (eds.), Studies in Vertebrate Evolution. Oliver and Boyd, Edinburgh.

Cox, C. B. 1991. The Pangaea dicynodont Rechnisaurus and the comparative biostratigraphy of Triassic dicynodont faunas. Palaeontology 34:767-784.

Dixey, F. 1926. Notes on the Karroo sequence north-west of Lake Nyasa. Transactions of the Geological Society of South Africa 29: 59-68. 
Gay, S. A., and A. R. I. Cruickshank. 1999. Biostratigraphy of the Permian tetrapod faunas from the Ruhuhu Valley, Tanzania. Journal of African Earth Sciences 29:195-210.

Gebauer, E. V. I. 2007. Phylogeny and evolution of the Gorgonopsia with a special reference to the skull and skeleton of GPIT/ RE/7113 ('Aelurognathus?' parringtoni). Ph.D. dissertation, Eberhard-Karls Universität Tübingen, Tübingen, Germany, 316 pp.

Haughton, S. H. 1926. On Karroo vertebrates from Nyasaland. Transactions of the Geological Society of South Africa 29:69-83.

Haughton, S. H. 1932. On a collection of Karroo vertebrates from Tanganyika Territory. Quarterly Journal of the Geological Society of London 88:634-671.

Huene, F. von. 1939. Die Karroofauna im ostafrikanischen RuhuhuGebiet. Zentralblatt für Mineralogie, Geologie, und Paläontologie B 1939:69-71.

Huene, F. von. 1942. Die anomodontier des Ruhuhu-Gebietes in der Tübinger Sammlung. Palaeontographica Abteilung A: Palaeozoologie-Stratigraphie 94:154-184.

Huene, F. von. 1944. Pareiasaurierreste aus dem Ruhuhu-Gebiet. Paläon-tologisches Zeitschrift 23C:386-410.

Huene, F. von. 1950. Die theriodontier des ostafrikanischen Ruhuhugebietes in der Tübinger Sammlung. Neues Jahrbuch für Geologie und Paläontologie, Abhandlung 92:47-136.

Jacobs, L. L., D. A. Winkler, K. D. Newman, E. M. Gomani, and A. Deino. 2005. Therapsids from the Permian Chiweta Beds and the age of the Karoo Supergroup in Malawi. Palaeontologia Electronica 8:1-23.

Kaaya, C. Z. 1992. Depositional environment of Late Permian Karoo beds in the Ruhuhu Basin and Mikumi area of Tanzania. Geologisches Institut der Universität zu Köln Sonderveröffentlichungen 83:1-126.

King, G. M. 1988. Anomodontia; pp. 1-174 in P. Wellnhofer (ed.), Encyclopedia of Paleoherpetology, Part 17C Gustav Fischer, Stuttgart.

King, G. M. 1992. The palaeobiogeography of Permian anomodonts. Terra Nova 4:633-640.

King, G. M., and B. S. Rubidge. 1993. A taxonomic revision of small dicynodonts with postcanine teeth. Zoological Journal of the Linnean Society 107:131-154.

Lee, M. S. Y. 1997. A taxonomic revision of the pareiasaurian reptiles: implications for Permian terrestrial palaeoecology. Modern Geology 21:231-298.

Mack, G. H., and M. R. Leeder. 1999. Climatic and tectonic controls on alluvial-fan and axial-fluvial sedimentation in the Plio-Pleistocene Palomas half graben, southern Rio Grande Rift. Journal of Sedimentary Research 69:635-652.

Maisch, M. W. 1995. Taxonomic revision of Cryptocynodon parringtoni v. Huene 1942 (Therapsida, Dicynodontia) from the Late Permian of Tanzania. Neues Jahrbuch für Geologie und Paläontologie, Monatshefte 1995:594-604.

Maisch, M. W. 1999. The tetrapods from the Late Permian of Tanzania in the collections of the Institut und Museum für Geologie und Paläontologie der Universität Tübingen, with special reference to the pristerodontian dicynodonts. Ph.D. dissertation, Eberhard Karls Universität Tübingen, Tübingen, Germany, $350 \mathrm{pp}$.

Maisch, M. W. 2000. Observations on Karoo vertebrates. Part 1. The taxonomic status of Rhachiocephalus usiliensis (von Huene, 1942) (Therapsida, Dicynodontia) from the Upper Permian Kawinga Formation of Tanzania. Neues Jahrbuch für Geologie und Paläontologie, Monatshefte 2000:15-28.

Maisch, M. W. 2002. Observations on Karoo and Gondwana vertebrates. Part 3: Notes on the gorgonopsians from the Upper Permian of Tanzania. Neues Jahrbuch für Geologie und Paläontologie, Monatshefte 2002:237-251.

Maisch, M. W. 2003. Lower jaw morphology and jaw adductor musculature of the giant Permian dicynodont Rhachiocephalus Seeley, 1898 (Therapsida) from the Late Permian of Tanzania. Geologica et Palaeontologica 37:89-106.

Maisch, M. W. 2004. Postcranial morphology of Rhachiocephalus Seeley, 1898 (Therapsida: Dicynodontia) from the Upper Permian of Tanzania and the status of Platypodosaurus robustus Owen, 1880. Geologica et Palaeontologica 38:161-175.

Maisch, M. W., and E. V. I. Gebauer. 2005. Reappraisal of Geikia locusticeps (Therapsida: Dicynodontia) from the Upper Permian of Tanzania. Palaeontology 48:309-324.
Nowack, E. 1937. Zur Kenntnis der Karruformation im Ruhuhu-Graben (D.O.A.). Neues Jahrbuch für Mineralogie, Geologie, und Paläontologie Abteilung B 78:380-412.

Panchen, A. L. 1959. A new armoured amphibian from the Upper Permian of East Africa. Philosophical Transactions of the Royal Society B 242:207-281.

Parrington, F. R. 1936. On the tooth-replacement in theriodont reptiles. Philosophical Transactions of the Royal Society of London B 226:121-142.

Parrington, F. R. 1946. On the cranial anatomy of cynodonts. Proceedings of the Zoological Society of London 116:181-197.

Romer, A. S., and L. I. Price. 1940. Review of the Pelycosauria. Geological Society of America Special Papers 28:1-538.

Rubidge, B. S. (ed.). 1995. Biostratigraphy of the Beaufort Group (Karoo Supergroup). South African Committee for Stratigraphy Biostratigraphic Series 1:1-46.

Rubidge, B. S. 2005. Reuniting lost continents - fossil reptiles from the ancient Karoo and their wanderlust. South African Journal of Geology 108:135-172.

Rubidge, B. S., and J. W. Kitching. 2003. A new burnetiamorph (Therapsida: Biarmosuchia) from the lower Beaufort Group of South Africa. Palaeontology 46:199-210.

Rubidge, B. S., and C. A. Sidor. 2002. On the cranial morphology of the basal therapsids Burnetia and Proburnetia (Therapsida: Burnetiidae). Journal of Vertebrate Paleontology 22:257-267.

Rubidge, B. S., C. A. Sidor, and S. P. Modesto. 2006. A new burnetiamorph (Therapsida: Biarmosuchia) from the Middle Permian of South Africa. Journal of Paleontology 80:740-749.

Schlüter, T., and R. Kohring. 1997. The fossil record of the Karoo in East Africa: history, palaeoecology and biostratigraphy. Neues Jahrbuch für Geologie und Paläontologie, Abhandlung 204:1-17.

Sidor, C. A., and B. S. Rubidge. 2006. Herpetoskylax hopsoni, a new biarmosuchian (Therapsida: Biarmosuchia) from the Beaufort Group of South Africa; pp. 76-113 in M. T. Carrano, T. Gaudin, R. Blob, and J. Wible (eds.), Amniote Paleobiology: Perspectives on the Evolution of Mammals, Birds, and Reptiles. University of Chicago Press, Chicago, Illinois.

Sidor, C. A., and R. M. H. Smith. 2007. A second burnetiamorph from the Permian Teekloof Formation of South Africa and its associated fauna. Journal of Vertebrate Paleontology 27:420-430.

Sidor, C. A., and J. Welman. 2003. A new specimen of Lemurosaurus pricei (Therapsida: Bumetiamorpha). Journal of Vertebrate Paleontology 23:631-642.

Sigogneau-Russell, D. 1989. Theriodontia I; pp. 1-127 in P. Wellnhofer (ed.), Encyclopedia of Paleoherpetology, Part 17B. Gustav Fischer, Stuttgart.

Smith, R. M. H. 1990. Alluvial paleosols and pedofacies sequences in the Permian lower Beaufort of the southwestern Karoo Basin, South Africa. Journal of Sedimentary Petrology 60:258-276.

Stockley, G. M. 1931. Reptilian remains of Karroo age. Annual Report of the Tanganyika Geological Survey 1930:6.

Stockley, G. M. 1932. The geology of the Ruhuhu coalfields Tanganyika Territory. Quarterly Journal of the Geological Society of London 88:610-622.

Stockley, G. M., and F. Oates. 1931. Report on geology of the Ruhuhu Coalfields. Bulletin of the Geological Survey of Tanganyika 2:1-68.

Tatarinov, L. P. 1968. [New theriodonts from the Upper Permian of the USSR]; pp. 32-46 in [Upper Paleozoic and Mesozoic amphibians and reptiles of the USSR], Nauka, Moscow. [Russian]

Weide, D. M., C. A. Sidor, K. D. Angielczyk, and R. M. H. Smith. In press. A new record of Procynosuchus delaharpeae (Therapsida: Cynodontia) from the Upper Permian Usili Formation, Tanzania. Palaeontologia Africana 44:21-26.

Wild, R., C. Kaaya, T. Kreuser, S. Markwort, and P. Z. Semkiwa. 1993. Discovery of a skull of Dicynodon lacerticeps in the uppermost Permian (Tatarian) of Tanzania. Sonderveröffentlichungen, Geologisches Institut der Universität zu Köln 70:231-242.

Wopfner, H. 2002. Tectonic and climatic events controlling deposition in Tanzanian Karoo basins. Journal of African Earth Sciences 34:167-177.

Wopfner, H., S. Markwort, and P. M. Semkiwa. 1991. Early diagenetic laumontite in the Lower Triassic Manda Beds of the Ruhuhu Basin, southern Tanzania. Journal of Sedimentary Petrology 61: 6572 . 